\title{
Enhancing Creativity through Ethnomathematics
}

\author{
Nuqthy Faiziyah, Sutama, Imroatus Sholihah, Septiani Wulandari, Dimas Aditya Yudha \\ Faculty of Teacher Training and Education, Universitas Muhammadiyah Surakarta (UMS), Surakarta, Indonesia
}

Received January 6, 2020; Revised May 20, 2020; Accepted May 28, 2020

Copyright $@ 2020$ by authors, all rights reserved. Authors agree that this article remains permanently open access under the terms of the Creative Commons Attribution License 4.0 International License

\begin{abstract}
Creative thinking is one of the important competencies to answer the challenges of the 21st century. The purpose of this study is to improve the ability to think creatively through learning mathematics based on culture (ethnomathematics). The research method used is action research. Learning is carried out using student worksheets that explore Surakarta batik. The subject of the research was Vocational High School students by taking the subject matter of Transformation Geometry. The results of the study showed that students' creativity could be increased through culture-based learning with a significant increase of $17,91 \%$. The new thing from this research is that learning is done using ethnomathematics student worksheets using a scientific learning approach that involves observing, questioning, experiencing, gathering information, associating, and communicating, creating.
\end{abstract}

Keywords Batik, Creativity, Ethnomathematics, Worksheets

\section{Introduction Section}

The development of information and communication technology makes it easier for humans to interact with each other without recognizing regional boundaries. This globalization era is characterized by changes in global demand for the workforce. This fact confronts us with the need for creative product design skills (Boix Mansilla \& Bughin, 2011).

Skills related to the globalization era, the first is learning and thinking skills which include communication and thinking skills. Second, is the ability related to skills in mastering information and communication technology (IT) which includes traditional skills namely surfing, keyboarding, and word processing as well as information literacy (IL) skills. The third skill is the ability to live and work in the 21st century with rapid change. These skills are related to citizenship ethics. Communication and thinking skills in details are communication, collaboration, critical thinking and problem solving, and creativity (Chu, Reynolds, Tavares, Notari, \& Lee, 2016). Among the four competencies, creativity is the most interesting competency to be studied more deeply. Creativity is defined as the ability to give birth to something new and different through an idea or a work. Originality of ideas that are creative in designing products is needed in the field of work.

The mathematical ideas to be considered developed out specific needs in the cultures involved(Katz, 2014). Mathematics is not just an activity of counting and studying abstract objects in the form of numbers and symbols, but also an activity of designing and calculating(Chu et al., 2016). Mathematics has been integrated in various fields of life, including the culture of the community. Culture is as a manifestation of habits, objects and tradition which is in heritage from generation to generation which still used by the inheritors (Dominikus, Wara S; Nusantara, Toto; Subanji; Muksar, 2017). Since 1985 many studies have discussed the relationship between mathematics and cultural activities, so a science called ethnomatematics has developed. Teachers and the public in general do not commonly say that mathematics and culture are connected. When teachers do acknowledge a connection, often they engage their students in multicultural activities merely as a curiosity (D’Ambrosio, 2001). Now ethnomatematics is part of learning mathematics in the classroom, especially the topic of geometry. Some of Indonesia's cultural heritage can be used as learning material for geometry transformation, one of which is batik motifs.

Batik is a cloth that is painted with the process of deepening with a certain pattern and given a certain coloring that contains meaning and art that is processed through a specific process (Ambarawati \& Agustin, 2019). Batik has characteristics of motifs/patterns and patterns. The motifs of Surakarta batik do not only contain elements of Javanese culture, but also elements of mathematics (Anggraeni, Mardiyana, \& Saputro, 2018). 
This study aims to develop students' creativity through Student Ethnographic Mathematics Worksheet. To obtain the good worksheet, it is carried out by reviewing scientific journals related to 21st century education, developing learning designs, and ethnomathematics. The worksheet is designed based on ethnomathematics by using a scientific approach that is observing, asking, trying, reasoning, communicating, and creating according to the 2013 Curriculum. Using this worksheet, it is expected that students' creativity can be developed through ethnomathematics-based learning designs.

\section{Creative Thinking}

Creative thinking is something that students must master in facing the challenges of the 21st century. It plays an important role not only in solving problems in school but also in dealing with everyday problems (Lince, 2016). Creative thinking is one of the characteristics of the high-thinking level which is a logical and divergent thinking method intended to build new ideas triggered by non-routine and challenging problems (Puspitasari, In, \& Syaifuddin, 2019). Mathematics learning should be one of subjects to increase creativity (Valéria, Rumanová, \& Pavlovi, 2014).

Creative thinking includes three things, namely using creative techniques with a broad range such as brainstorming, generating new and valuable ideas including both incremental and radical concepts, and Elaborate, refine, analyze and evaluate their own ideas (Piirto, 2011). One good method for increasing students' creativity is to give open-ended questions. In addition, one of the things that can support students' creativity is connecting with realities that are close to students(Chamberlin \& Mann, 2019).

Creativity can be encouraged through effectiveness in the classroom. Having a learning rather than a performance orientation, helps to create an environment where creativity is encouraged (Márquez, Ontiveros, \& Pons, 2016). Creative skills could also be increased by the learning and practice techniques to improve and develop the teachers' cognitive flexibility and intellectual independence.

\section{Ethnomathematics Learning}

Mathematics has been integrated in various fields of life, including in the culture of the community. The term ethnomatematics was first introduced by Ubiratan D'Ambrosio in 1985. He stated that ethnomatematics is mathematics that is used in identifiable cultural groups. Ethnomatematics is a field of study that studies the relationship between mathematics and culture. Proven existence of mathematical concepts is contained in the building of temples and inscriptions, local units of the Sidoarjo community, traditional earthenware geometric shapes, batik cloth motifs and embroidery (Rahmawati, 2016). Learning math based on culture can become a solution to introduce the culture and learning math(Maryati \& Indra Prahmana, 2018). Further, The use of cultural artifacts to facilitate mathematics learning is a conscious and systematic effort in preserving culture and in broadening views of what counts as mathematical knowledge (Dominikus, Wara S; Nusantara, Toto; Subanji; Muksar, 2017).

The learning is designed using scientific approach involving activities of observing, questioning, experimenting, gathering information, associating, and communicating, creating. Scientific approach is a learning process designed so that participanted students actively construct concepts, law or principle through stages observe (to identify or finding a problem), formulating a problem, put forward or formulate a hypothesis, collect data with a variety of technique, analyze data, draw conclusions and communicating concepts, law or "discovered" principle (Sufairoh, 2016). Teachers need to prepare learning materials that encourage students to do scientific activities including observing, questioning, experimenting, gathering information, associating, and communicating, creating. (Leksono, 2015). The observing prefers meaningful learning process. The observation stage is very useful for fulfilling students' curiosity. So the learning process has a high meaningfulness. The activity of observing in learning begins with the teacher opening widely and varyingly to students to make observations through activities; look, listen, hear and read (Kemendikbud, 2013). In this activity students observe images of Slobog batik motifs as follows instructions. 


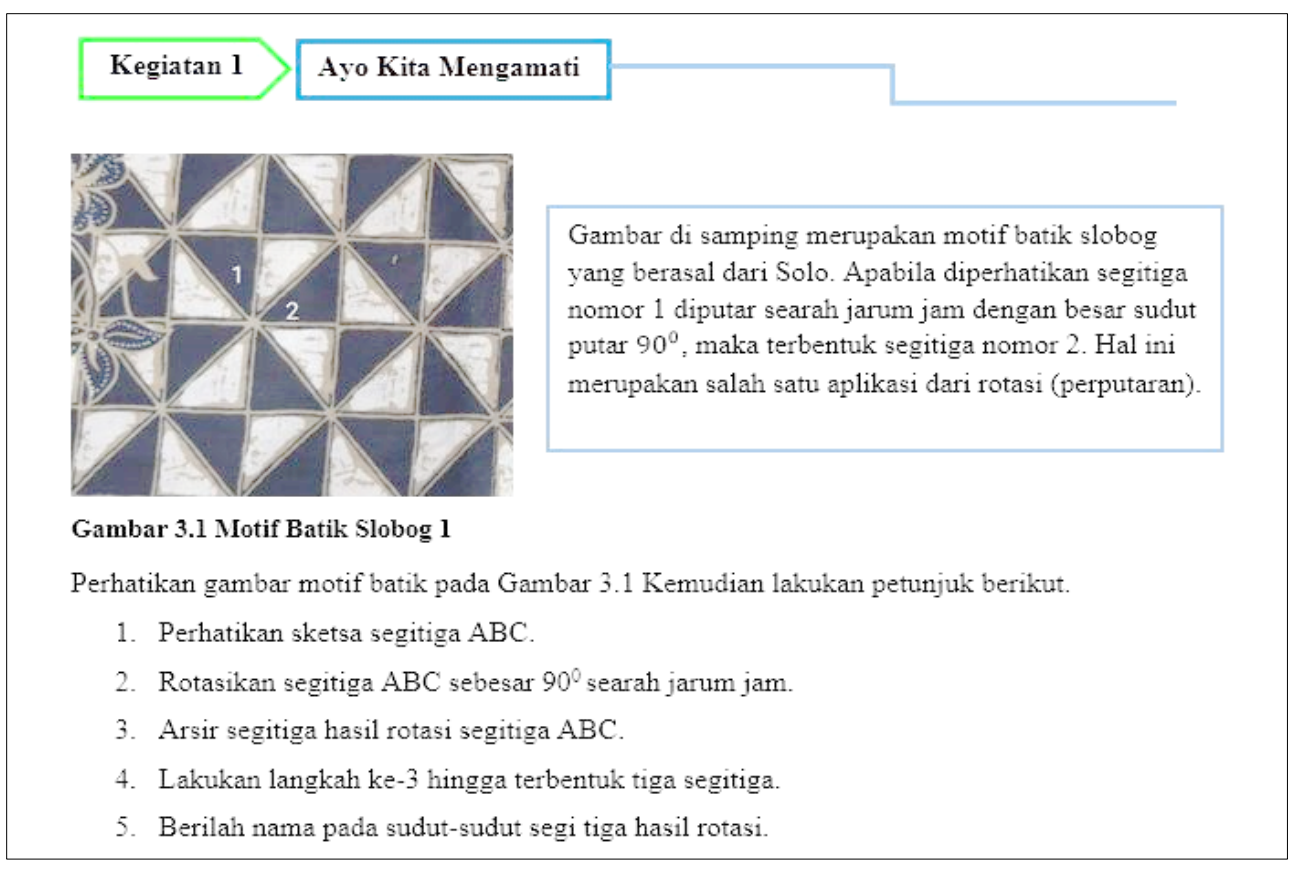

Figure 1. Observing Activities

In observing activities, students observe the Slobog batik motif on student worksheet. the students were asked to draw a triangle and rotate by $90^{\circ}$ to form a Slobog batik motif. All students carried out these activities smoothly and precisely. Figure 2 below is one of student's response in observing activities.

5. Berilah nama pada sudut-sudut segi tiga hasil rotasi

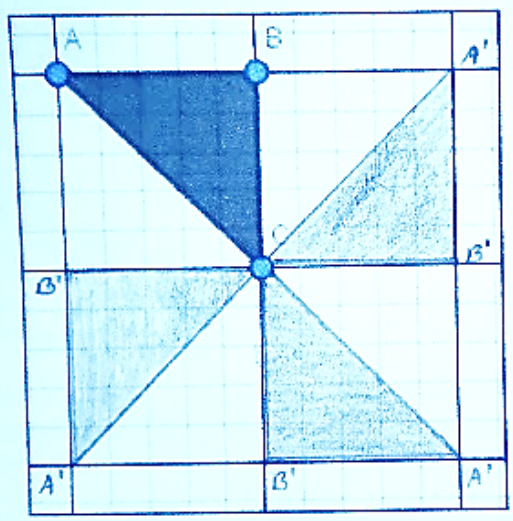

Figure 2. Student's Response in Observing Activities

The questioning activity in learning activities is asking questions about information that is not understood from what was observed or questions to get additional information about what was observed, starting from factual questions to hypothetical questions. The competence expected in this activity is to develop creativity, curiosity, the ability to form questions to form critical thoughts that need to live smart and lifelong learning. In observing activities, the teacher opens broad opportunities for students to ask questions about what they have seen, listened to, read or heard (Kemendikbud, 2013). The competencies developed are creative, curiosity, the ability to formulate questions to form critical thoughts that need to live smart and lifelong learning. The questioning activity tests students so that they are active in asking questions about ongoing learning. The teacher as a facilitator guides students to be able to ask questions. The teacher provokes students until students can ask questions of their own minds from the desire to know that arises in these students (Hosman, 2014).

At this activity, students are asked to arrange questions related to information that they have obtained at the observing. In Figure 3, here are questioning activities and student's response in stating questions.

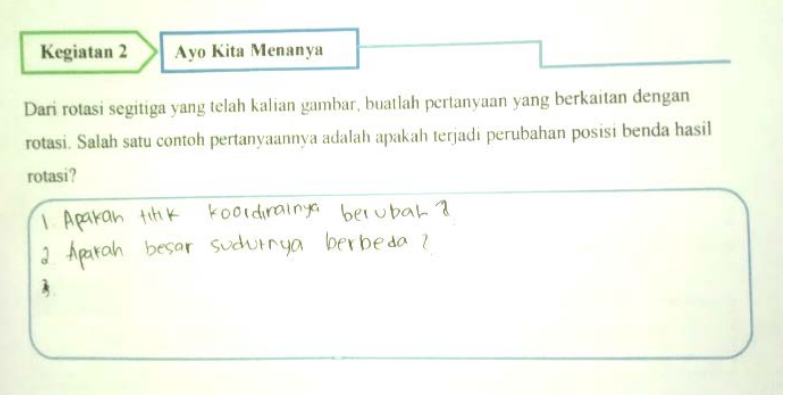

Figure 3. Questioning Activities and Student's Response

The questions about rotations submitted by students varied. The following is a list of questions asked by students. 
Table 1. The Questions of Student Asking

\begin{tabular}{|c|c|}
\hline No & Questions \\
\hline 1 & What is the meaning of rotation? \\
\hline 2 & Is rotation may change the shape of a triangle? \\
\hline 3 & $\begin{array}{l}\text { Why rotation must be clockwise, is it allowed to be } \\
\text { clockwise? }\end{array}$ \\
\hline 4 & $\begin{array}{l}\text { Does the rotation direction affect the value of the rotation } \\
\text { angle? When rotating clockwise or counter clockwise? }\end{array}$ \\
\hline 5 & Why does angle $\mathrm{C}$ always rise in the middle? \\
\hline 6 & Have the coordinates changed? Is the angle different? \\
\hline
\end{tabular}

In this activity, students are asked to try to rotate the ABC triangle with A $(0,0), \mathrm{B}(1,1)$ and $\mathrm{C}(1,0)$ rotated $90^{\circ}$ clockwise with center B (1.1) in the Cartesian plane, as well as writing down the coordinates of the results of the triangle triangle $\mathrm{ABC}$.

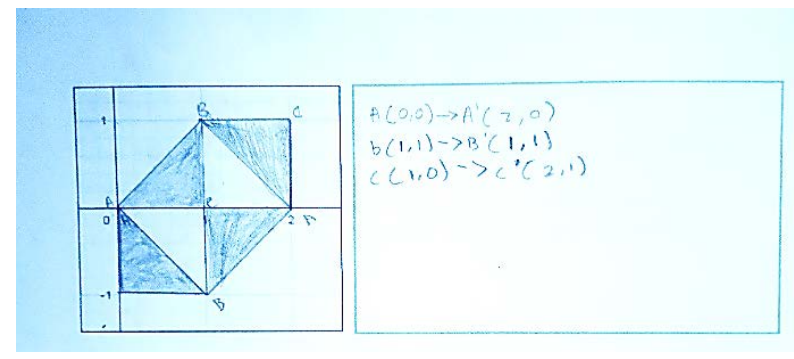

Figure 4. Student's Response on Experiencing Activity

The activity of gathering information is a further act of the questioning activity. This activity is carried out by exploring and gathering information from various sources through various means. For that students can read more books, pay attention to phenomena or objects that are more researched, or even conduct experiments. From this activity a number of information is collected. Information gathering activities are carried out through experiments, reading, sources other than textbooks, observing objects or events, interviewing with resource persons and so on (Kemendikbud, 2013). The expected competence is to develop a conscientious, honest, polite attitude, respect the opinions of others, the ability to communicate, apply the ability to gather information through various ways learned, and develop learning habits (Daryanto, 2014).

The ability to associate information through reasoning and rational thinking is an important competency that must be possessed by students. The activity of associating in learning activities is processing information that has been collected both limitedly from the results of the gathering and experimentation activitiesas well as the results of observing and collecting information activities. The processing of information is collected from those that add breadth and depth to the processing of information that is looking for solutions from various sources that have different opinions to the contrary. This activity is carried out to find the linkage of one information with other information, find patterns from the linkage of that information (Kemendikbud, 2013). Information obtained from observations or experiments conducted must be obtained to find the linkage of one information with other information. Associating activities require that students must have more insight than the teacher. Based on the information obtained by students, students must go deeper into the problems found and must be solved (Sani, 2014).

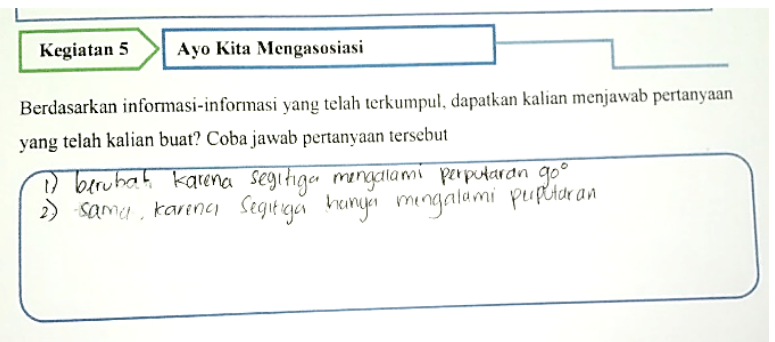

Figure 5. Associating Activity

In associating activities, students are asked to answer questions they make based on information that they have obtained from various sources. Student's responses on association activity can be sawn in table 2 .

Table 2. Student's Responses on Association Activity

\begin{tabular}{cl}
\hline No & \multicolumn{1}{c}{ Answers } \\
\hline 1 & $\begin{array}{l}\text { Transformation that moves the points by rotating them as } \\
\text { far as the center of a particular point. }\end{array}$ \\
2 & $\begin{array}{l}\text { No, because rotation does not change the angle of the } \\
\text { object. }\end{array}$ \\
3 & $\begin{array}{l}\text { No, the rotational position is not always parallel but the } \\
\text { shape of the rotated object must always be the same. } \\
\text { Yes, if the rotation is counter clockwise, then the result is } \\
\text { positive. If the rotation is clockwise, the result is negative. }\end{array}$ \\
4 & $\begin{array}{l}\text { If the rotation is counter clockwise, then the rotation angle } \\
\text { is positive. If the rotation is clockwise, the angle of } \\
\text { rotation is negative. } \\
\text { Because point } C \text { is the center point } \\
\text { Change, because triangles experience } 900 \text { turns. Same, } \\
\text { because triangles only turn around. }\end{array}$ \\
\end{tabular}

In the scientific approach teachers are expected to provide opportunities for students to communicate what they have learned. This activity can be done through writing or telling what is found in the activities of finding information, associating and finding patterns. The results are delivered in class and are assessed by the teacher as a learning achievement of the students or groups of students. Communicating activities in learning activities are to submit observations, conclusions based on the results of analysis verbally, in writing, or other media. In communicating activities, students are asked to provide conclusions from various activities that have been carried out according to student's worksheet instructions. The following conclusions are given by students. 
Table 3. Student's Responses on Communicating Activity

\begin{tabular}{|c|c|}
\hline No & Conclusion \\
\hline 1 & $\begin{array}{l}\text { This is the definition of Rotation. Rotations can produce } \\
\text { certain patterns }\end{array}$ \\
\hline 2 & $\begin{array}{l}\text { Rotation does not change the angle of an object, it only } \\
\text { changes its coordinate position. }\end{array}$ \\
\hline 3 & That rotation can form a pattern on a batik. \\
\hline 4 & $\begin{array}{l}\text { Rotation is the rotation from one point to another as far as } \\
\text { theta and can use coordinates. }\end{array}$ \\
\hline 5 & $\begin{array}{l}\text { Rotated-shape do not change shape. Rotated buildings } \\
\text { undergo changes in position. }\end{array}$ \\
\hline 6 & Rotation can produce a motive for regular art work. \\
\hline 7 & $\begin{array}{l}\text { In conclusion, rotation is the displacement of points by } \\
\text { rotating these points as far as zero at the center of a particular } \\
\text { point }\end{array}$ \\
\hline
\end{tabular}

In creating activities, students are asked to create new batik motifs according to the following provisions. Discuss with your group to solve the following problem. Make a batik motif with a flat shape and use a rotation of $\alpha$ with center $\mathrm{O}(0,0)$ or rotation of $\alpha$ with Center $\mathrm{P}(\mathrm{p}, \mathrm{q})$.

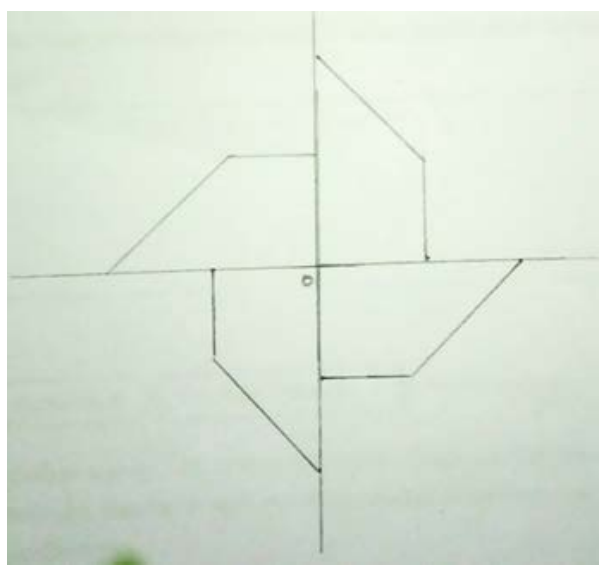

Figure 6a. Batik Motif 1

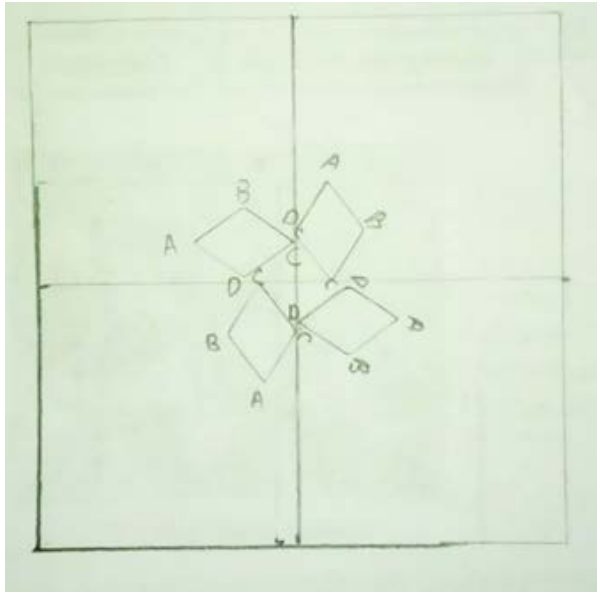

Figure 6b. Batik Motif 2

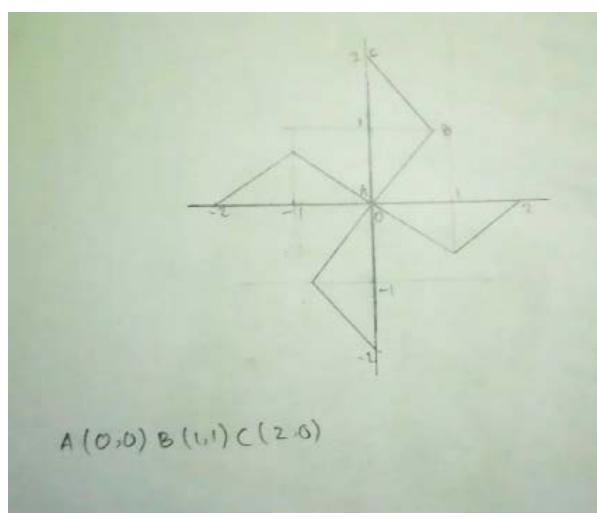

Figure 6c. Batik Motif 3

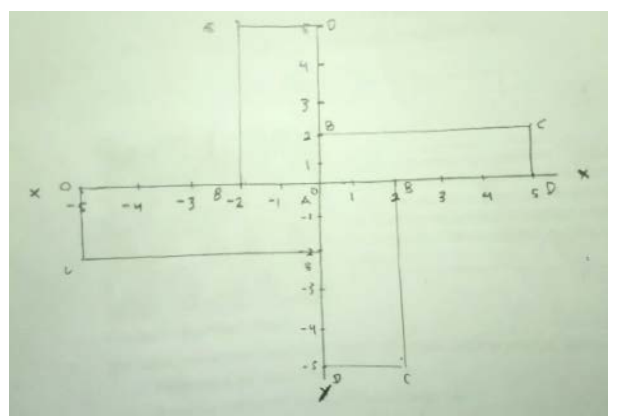

Figure 6d. Batik Motif 4

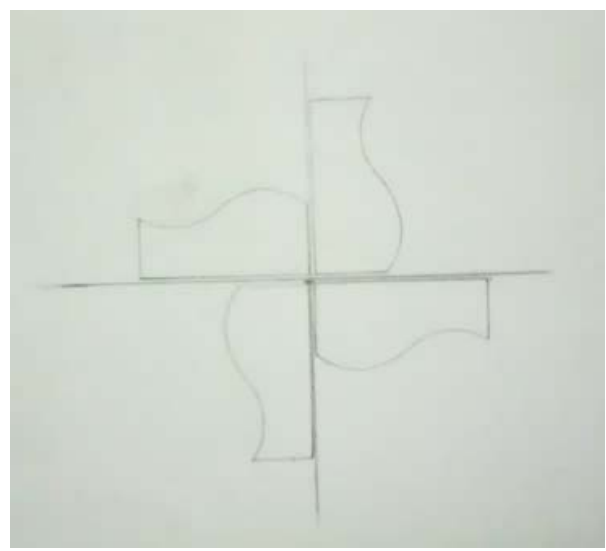

Figure 6e. Batik Motif 5

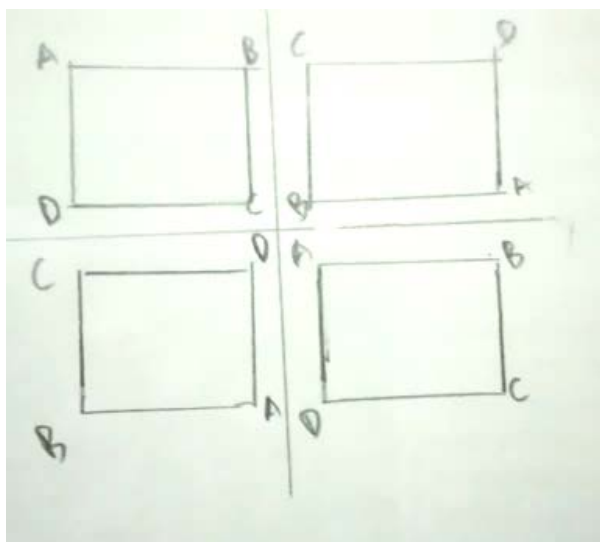

Figure 6f. Batik Motif 6 
Table 4. Creativity Score

\begin{tabular}{ccccccc}
\hline & \multicolumn{5}{c}{ Aspects } & Incrase \\
\cline { 2 - 5 } & Fluently & Flexibility & Elaboration & Orisinality & Creativity & \\
\cline { 3 - 5 } Before & $74.57 \%$ & $71.52 \%$ & $60.74 \%$ & $67.04 \%$ & $68.30 \%$ & $17.91 \%$ \\
\hline \multirow{2}{*}{ After } & $74.29 \%$ & $75.71 \%$ & $71.43 \%$ & $82.86 \%$ & $86.21 \%$ & \\
\hline
\end{tabular}

The results of scoring creativity through ethnomatemics-based worksheet obtained results of $74.29 \%$ for the aspect of fluency of thinking, $75.71 \%$ for flexibility of thinking, $71.43 \%$ for elaboration, $82.86 \%$ for originality, so that the creativity of students through worksheet activities amounted to $76.00 \%$. Students' creativity in learning mathematics before ethnomathematics learning is to $68.30 \%$, while with activities with worksheet based on ethnomatematics students' creativity was $76.00 \%$. This figure increased by 17, $91 \%$.

Similar research was also carried out by Ayu Wulandari et al, in 2018 with the title Development of Student Worksheets on Jambi Culture-Based Geometry Materials to Increase Student Creativity. In this research, a culture-based Worksheets was developed in a Jambi culture-based mathematics Worksheets on the geometry of a flat figure to increase students' creativity. To obtain a comparison, researchers used pretest and posttest as mathematical representations, so that through the Gain test result obtained is 0.7 , which means that the results are high, namely effective. At the end of the study, researchers used students' questionnaires to obtain students' perceptions about the use of Worksheets. The result is that 95\% of students perceive Worksheets as very good.

In the research and development of Ariaji and Abu Bakar (2017), the worksheets were developed by integrating character values, effectively implementing learner-centered learning. Through discussions in student's worksheet, students are more motivated to discuss and give individual thought. This makes students come up with answer strategies that vary. The use of enthnomathematics in learning has also been done by (Lestaringsih; Mulyono, 2017) learning geometry. In conclusion, after the achievement of some basic concepts of transformation, students are able to solve problems at the formal level by using their knowledge and experience at the situational, referential and general levels.

\section{Conclusions}

Indonesian batik motifs can be used for learning geometry of transformation because in the design activity found the concept of transformation. Through Ethnomatematics-Based Students Worksheets, students can improve thinking fluency, flexibility of thinking, elaboration, and originality as aspects measured in creativity. Based on a questionnaire filled out by 27 students, the results of students' thinking fluency were $74.57 \%$, flexibility of thinking was $71.52 \%$, elaboration was $60.74 \%$, and originality was $67.04 \%$. In general, students' creativity reached $68.30 \%$.

Student Worksheets are developed according to the needs and development of students' abilities through a scientific approach, which is observing, questioning, reasoning, communicating, and creating. The results of scoring creativity through ethnomatemics-based worksheet obtained results of $74.29 \%$ for the aspect of fluency of thinking, $75.71 \%$ for flexibility of thinking, $71.43 \%$ for elaboration, $82.86 \%$ for originality, so that the creativity of students through student worksheet activities amounted to $76.00 \%$. Students' creativity in learning mathematics through before ethnomathematics learning 68.30\%, while with activities with stundent worksheet based on ethnomatematics students' creativity, was $76.00 \%$. This figure increased by 17, $91 \%$.

\section{Acknowledgement}

Thank you Universitas Muhammadiyah Surakarta.

\section{REFERENCES}

[1] Ambarawati, M., \& Agustin, R. D. (2019). Ethnomatematics as Indonesia Batik Artwork in Mathematics Learning Two-dimensional Figure Materials. International Journal of Scientific and Research Publications (IJSRP), 9(9), p9305. https://doi.org/10.29322/ijsrp.9.09.2019.p9305

[2] Anggraeni, M. K., Mardiyana, M., \& Saputro, D. R. S (2018). Geometric Transformation in Surakarta Batik Patterns. Advances in Intelligent Systems Research (AISR), 157, 93-95. https://doi.org/10.2991/miseic-18.2018.22

[3] Boix Mansilla, V., \& Bughin, J. (2011). Preparing Our Youth to Engage the World. Educating for Global Competence, 1-136. Retrieved from papers2://publication/u uid/CB6743CB-9C89-4AAF-831E-5124907F4569

[4] Chamberlin, S. A., \& Mann, E. (2019). Factors that Influence Mathematical Creativity. The Mathematicd Enthusiast, 16(1). 
[5] Chu, S. K. W., Reynolds, R. B., Tavares, N. J., Notari, M., \& Lee, C. W. Y. (2016). 21st century skills development through inquiry-based learning: From theory to practice. 21st Century Skills Development Through Inquiry-Based Learning: From Theory to Practice, (January), 1-204. https://doi.org/10.1007/978-981-10-2481-8

[6] D'Ambrosio, U. (2001). What is ethnomathematics, and how can it help children in schools? Teaching Children Mathematics, 7(6), 308-310. Retrieved from http://www.jst or.org/stable/41199887

[7] Daryanto. (2014). Pendekatan Pembelajaran Saentifik Kurikulum 2013. Yogyakarta: Gava Media.

[8] Dominikus, Wara S; Nusantara, Toto;Subanji; Muksar, M. (2017). Ethnomathematical Ideas in The Weaving Practice of Adonara Society. Journal of Mathematics and Culture, 11(4), 83-95.

[9] Hosman. (2014). Pendekatan Saintifik Dan Kontekstual Dalam Pembelajaran Abad 21.

[10] Katz, V. J. (2014). in the Ethnomathematics Classroom, 14(2), 26-30.

[11] Kemendikbud. Permendikbud 81A-2013Implementasi Kurikulum 2013 (2013).

[12] Leksono, J. W. (2015). Pendekatan Saintifik pada Kurikulum 2013 untuk Meningkatkan Keterampilan Berpikir Kritis Siswa. Proceedingfptk.

[13] Lestaringsih; Mulyono, I. (2017). DESAIN PEMBELAJARAN TRANSFORMASI MENGGUNAKAN MOTIF BATIK TULIS SIDOARJO. Jurnal Edukasi, 3(1), 83-98.
[14] Lince, R. (2016). Creative Thinking Ability to Increase Student Mathematical of Junior High School by Applying Models Numbered Heads Together. Journal of Education and Practice, 7(6), 206-212.

[15] Márquez, B. V., Ontiveros, M. Á. C., \& Pons, M. O. (2016). The small temples in the forum of Pollentia (Mallorca, Balearic Islands). Mélanges de l'École Française de Rome. Antiquité, 11(128-1), 53-74. https://doi.org/10.4000/mefra. 3428

[16] Maryati, M., \& Indra Prahmana, R. C. (2018). Ethnomathematics: Exploring the Activities of Designing Kebaya Kartini. MaPan: Jurnal Matematika Dan Pembelajaran, 6(1), 11-19. https://doi.org/10.24252/mapan .2018v6n1a2

[17] Piirto, J. (2011). Creativity for 21st. Rotterdam: Sense Publishers.

[18] Puspitasari, L., In, A., \& Syaifuddin, M. (2019). Analysis of Students' Creative Thinking in Solving Arithmetic Problems. International Electronic Journal of Mathematics Education, 14(1), 49-60.

[19] Sani. (2014). Pembelajaran Saintifik untuk Implementasi 2013. Jakarta: PT. Bumi Aksara.

[20] Sufairoh. (2016). PENDEKATAN SAINTIFIK \& MODEL PEMBELAJARAN K-13. JURNAL PENDIDIKAN PROFESIONAL, 5(3), 116-125. https://doi.org/10.26555/b ahastra.v37i1.5641

[21] Valéria, Š., Rumanová, L., \& Pavlovi, G. (2014). Support of Pupil's Creative Thinking in Mathematical Education. Procedia - Social and Behavioral Science, 116, 1715-1719. https://doi.org/10.1016/j.sbspro.2014.01.461 